\title{
Transgenic Animal
}

National Cancer Institute

\section{Source}

National Cancer Institute. Transgenic Animal. NCI Thesaurus. Code C14184.

Experimental org anism whose genome has been altered by the transfer of a gene or genes from another species or breed. 